\title{
Inflation Continues
}

NFLATION has been a major concern of public policy for well over two years. In the first half of 1967 the Administration suggested passage of an income surtax to curb mounting inflationary pressures, and as early as December 1967 monetary authorities indicated a desire to restrain the overly exuberant economy. Yet, effective restrictive action was long delayed, and the persisting inflation has actually accelerated. Consumer prices have risen at more than a 6 per cent annual rate since last December, up from the 1968 rate of 4.7 per cent. This compares with a 3 per cent average annual increase in 1966 and 1967, and a 1.4 per cent trend rate from 1957 to 1965 .

This article attempts to provide some insight into the problem of inflation by focusing on a few key questions. What is inflation? How does inflation affect the economy? What has caused the inflation since 1965? How can it be combated? What has been done in recent months to halt inflation? And, when may we expect moderation of inflation to be achieved?

\section{What is Inflation?}

Inflation is a rise in the general level of prices, or stated differently, a decline in the overall purchasing power of the dollar. Inflation does not necessarily involve an increase in the price of every good or even of every group of goods. Increases and decreases in prices of particular goods or services, which reflect changes in stpplies or demands, are essential for the smooth operation of an efficient economy. Rising prices in one sector may be accompanied by declining prices elsewhere, and the changes in relative prices give incentive for transferring resources to areas where demands are greatest.

How then can we know how much inflation has occurred? The rate of inflation is difficult to measure accurately since there are myriad prices, some of which are rising and others falling, and since there are continuous changes in the quality and composition of goods and services offered for sale. The standard measures of the rate of inflation are derived from changes of prices of fixed "baskets" of goods and services. This assumes that changes in quality, tastes, and relative prices are either insignificant, or that adequate adjustments can be made for them. Frequently used measures include the

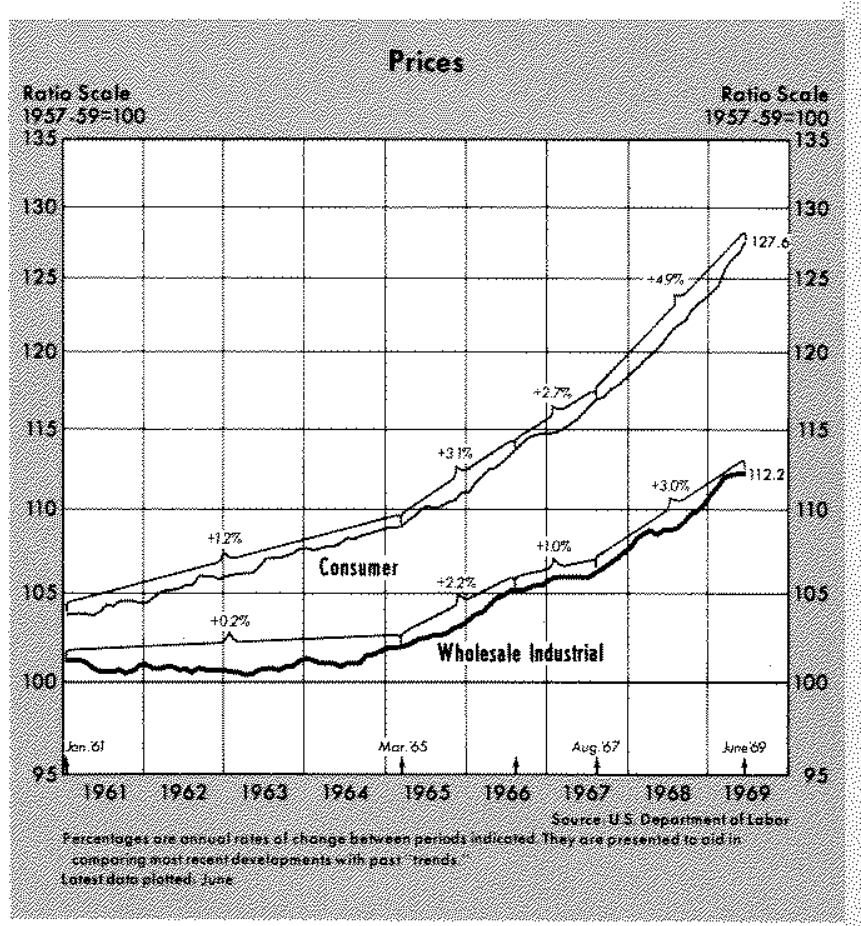

Consumer Price Index, the Wholesale Price Index, and the Implicit Price Deflator.

The Consumer Price Index, which is compiled by the Bureau of Labor Statistics, is a measure of changes in prices of selected goods and services purchased by urban wage earners and clerical workers. The index covers the prices of most things people buy food, clothing, automobiles, homes, furnishings, drugs, doctor expenses, repair costs, transportation fees, and others.

The Wholesale Price Index, also compiled by the BLS, is a measure of the composite price movements in primary markets. The index is based on price quotations for approximately 2,300 commodities selected to represent all commodities sold in primary markets in the United States.

The Implicit Price Deflator is computed by the Department of Commerce as a part of the national income statistics. It is gross national product in current dollars divided by gross national product in 1958 prices and thereby measures the change in prices of all goods and services weighted by amount spent on each item. The deflator is available quarterly, and the consumer and wholesale measures are available monthly. 


\section{Effects of Inflation}

Inflation in the American economy causes redistributions of wealth and income and creates inefficiencies, injustices, and uncertainties. Inflation has different effects on the economy and on individuals, depending on the extent to which it has been anticipated and the extent to which these anticipations have been acted upon. Unexpected inflation causes a redistribution of wealth from those who have extended credit to those who have borrowed. For a loan at 5 per cent interest for a year when prices rise 6 per cent, the lender receives a net real yield of minus one per cent, since he is repaid with dollars that will buy fewer goods than when he made the loan.

If the degree of inflation were exactly anticipated and provided for by everyone, there would be no redistribution of wealth or income, since adjustments for the anticipated rate of price level increases would be built into contracts. If both the borrower and lender anticipated the 6 per cent inflation in the previous example, and the funds were worth a real net 5 per cent to the borrower, the contract would have been made for an 11 per cent nominal rate of interest. ${ }^{1}$

Of course, there is much uncertainty about the course of future prices, and all people are not capable of making contracts against such contingencies, especially when the rate of inflation varies. Returns on money holdings (since money is non-interest bearing) cannot be adjusted for reduced purchasing power. Many long-term contracts such as mortgage loans are already in existence, and cannot be changed until they mature. Others cannot be modified by the participants; changes in Social Security benefits, for: example, are at the discretion of the Government.

There is evidence that adjustments to the present rate of inftation have not been complete. Many longterm loans, pensions, and annuities are returning the lender less purchasing power than he had at the time of the agreement. Even though growth in output per man hour has probably slowed only slightly from its trend of 3 per cent or more per year, hourly wages of nonagricultural workers rose 6 per cent in the past twelve months, while consumer prices went up 5.5 per cent. By comparison, in the previous year wages rose 6.4 per cent and prices 4.2 per cent.

Income tax considerations would make the actual rate higher, since the borrower is able to deduct from his income the amount of interest paid, and the lender must include as income the greater amount of interest received.
One adjustment to expected inflation is higher interest rates. An adequate adjustment in rates is impossible in some sectors, however, since it would conflict with legal ceilings. This is generally most harmful to small borrowers and savers who rely principally on the regulated financial institutions, and are most hindered by state usury laws. For example, it has been impossible for small consumers even to maintain the purchasing power of their savings accounts in banks. The legal maximum on these accounts is 4 per cent, but consumer prices have gone up at a 6 per cent rate since December. Moreover, consumers must pay income taxes on these "earnings." Those who deal in larger amounts are able to borrow or lend desired funds with fewer restrictions.

Inflation in conjunction with a progressive tax system contributes to an expansion of the Federal Government. Rising price levels raise nominal incomes and move taxpayers into higher tax brackets. As a result the Government receives a greater percentage of total real, as well as nominal, income. On the other hand, local governments, which rely heavily on property taxes for revenue, usually suffer a decline in real income during periods of inflation, since assessed valuations are relatively fixed.

Inflation also affects international payments balances. Higher interest rates in this country than in others tend to cause a surplus in this nation's capital account as long as there is no widespread anticipation of a change in exchange rates. Higher prices in this country adversely affect our trade balance.

Inflation greatly increases incentives for economizing cash balances. With rapid price increases it is advantageous for individuals and businesses to spend more effort in keeping money balances at a minimum.

In theory, only if the rate of inflation were stabilized, with all the public fully anticipating it and acting upon the anticipations intelligently and costlessly, would the rate of inflation be immaterial. But, under present conditions of uncertainty, nonuniform expectations, and lack of flexibility, inflation is highly undesirable, and it is the stated policy of the Government to eliminate it.

\section{What Causes Inflation?}

Inflation results mainly from a greater dollar demand for goods and services than the economy is able to produce at existing prices. At the onset of a period 
of rapid spending growth, real product and employment may increase rapidly for a time and prices relatively little. But, as employment of resources approaches capacity and bottlenecks appear, price increases accelerate and the growth rate in real output moderates.

From 1961 to 1964 the U.S. economy was recovering from a situation of under-utilization of resources. Real product grew at a 5.4 per cent annual rate, well in excess of the trend growth rate of production, and prices increased at a 1.3 per cent rate. But since 1964, production has been at or near capacity most of the time, and total spending has continued to grow at rates about twice that of production. As a

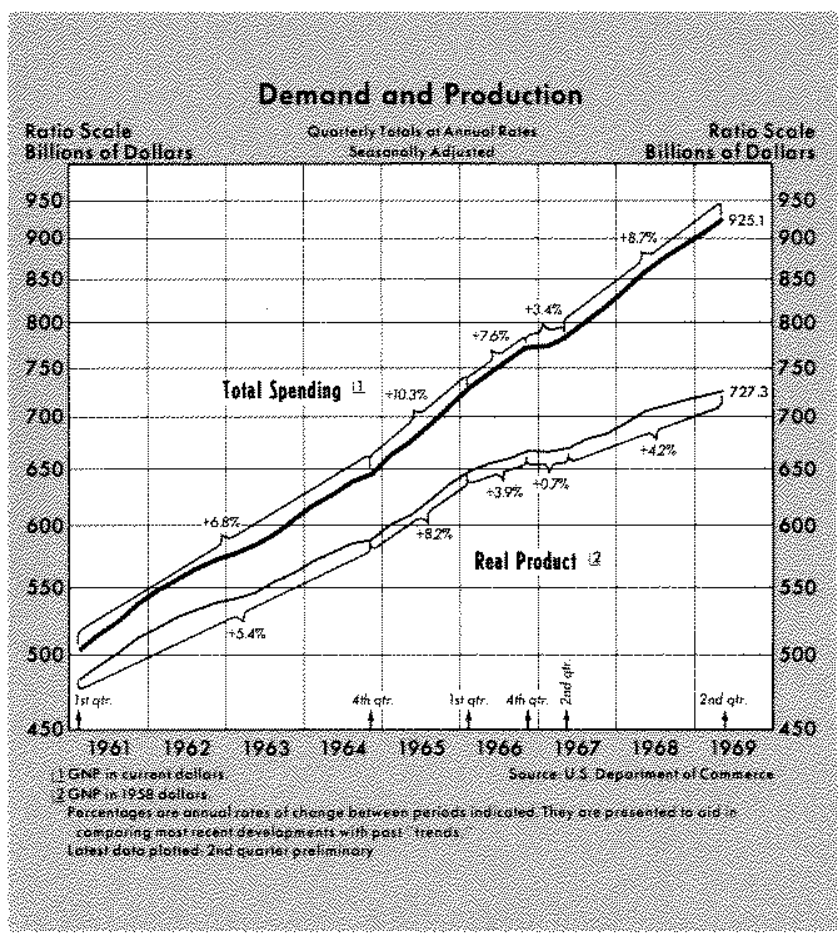

result, prices have risen rapidly. During the past year the GNP price deflator has gone up at a 4.5 per cent rate, and real product has grown at about a 3 per cent rate.

\section{Possible Causes of Recent Inflation}

A major disagreement about inflation centers on its causes and cures. Three main schools of thought may be distinguished: fiscal, monetary, and institutional.

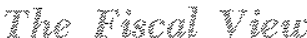

Some observers ascribe the inflation since 1965 chiefly to the course of Federal spending and taxation. One analytical measure of the thrust of fiscal actions is an estimate of the national income accounts

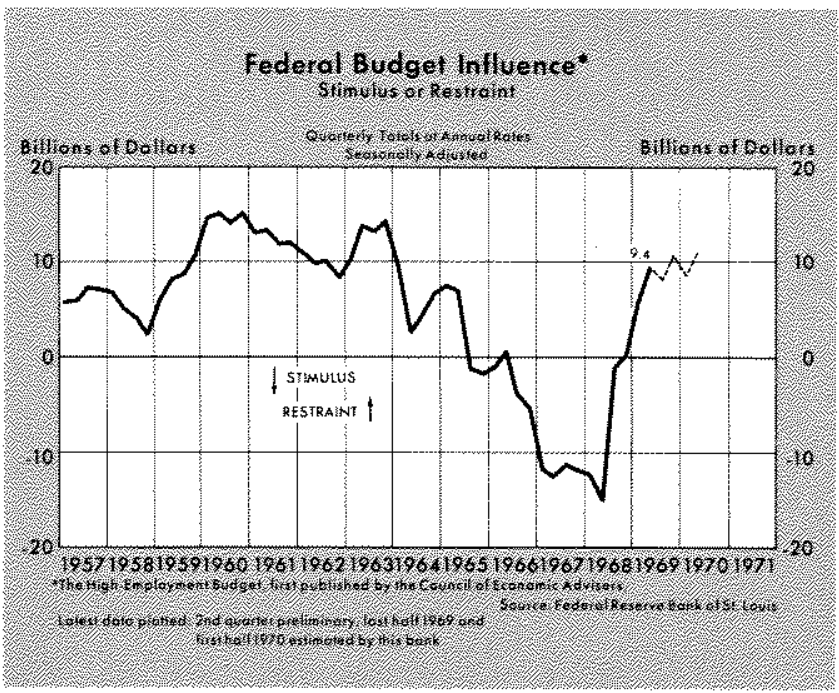

budget which would prevail at a constant rate of resource use, the so-called "high-employment" budget. By eliminating the effect of changing levels of economic activity on Government receipts and expenditures, the high-employment budget is believed to indicate the impact of changes in tax laws and in legal provisions for expenditures." A surplus of receipts over expenditures is presumed to be indicative of Governmental restraint on total spending, and, conversely, greater expenditures than receipts imply Governmental stimulus to total spending.

The high-employment budget surplus declined from an annual rate of $\$ 12$ billion in 1960-63 to about balance in the last half of 1965 , as taxes were reduced and Government spending rose rapidly. The high-employment budget then moved to a deficit of more than a $\$ 12$ billion annual rate from early 1967 to mid-1968.

Government expenditures taken alone are another possible indicator of the fiscal impact on the economy, and have been used to explain the recent inflation. The expansion of the Vietnam conflict, together with rapid growth of non-defense expenditures, resulted in rapid acceleration of total Government outlays. Federal expenditures rose at a 15 per cent annual rate from mid-1965 to mid-1968, after rising at a 6 per cent rate from 1957 to 1965.

Fiscal views of the cause of inflation imply that if these expansionary developments had not taken place, the excessive growth of total spending might have been avoided, or at least limited. These views were the basis for the long-debated proposals for a tax increase and/or Government expenditures restraint,

2See "Estimates of the High-Employment Budget: 1947-1967", this Review, June 1967. 
which culminated in the 10 per cent surtax in mid1968 and some cuts in proposed spending. Passage of the tax bill resulted in moving the high-employment budget to a surplus of about an $\$ 8$ billion seasonally adjusted annual rate in the first half of 1969. Government expenditure growth also slowed. Expenditures increased 6 per cent in the last twelve months, after growing at the 15 per cent rate in the preceding three years.

A review of economic developments during recent years raises some question as to the influence of fiscal actions on total spending. In the 1961-63 period the country experienced rapid growth of total spending, real product, and employment, though the high-employment surplus was large and the rise in Government spending was not exceptionally rapid. In early 1967 growth of total private and Government spending decelerated markedly, though the high-employment deficit and Government outlays increased rapidly from mid-1966 to mid-1967. Again, the substantial tightening of the budget after June 1968 appears to have exercised little observable restraint on spending. Total spending on goods and services has grown 7.7 per cent in the past year, similar to the 8.3 per cent rate in the previous three years.

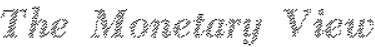

Monetary developments provide an alternative or supplementary explanation of changes in total spending and of inflation. While specialists differ on how to measure monetary actions, we may roughly distinguish two main current views on how monetary developments are measured: money market conditions and monetary aggregates.

The course of the money stock, the most frequently used monetary aggregate, may be viewed as explaining in large measure the general course of total spending. The acceleration of money growth from the 195361 average annual rate of 1.4 per cent to a 3 per cent rate from 1961 to early 1965 was accompanied by recovery and expansion in the early Sixties. From the spring of 1965 to the spring of 1966 money rose 6 per cent, and both spending and inflationary pressures accelerated. The nine-month pause of monetary growth in 1966 was followed by a deceleration of spending growth in early 1967. Resumption of rapid growth of money in early 1967 appears to be related to the acceleration of total spending growth and of inflation since mid-1967.3

${ }^{3}$ These relations have been demonstrated with greater statistical precision by "Monetary and Fiscal Actions: A Test of Their Relative Importance in Economic Stabilization," this Review, November 1968.
Many analysts feel that money market conditions, measured possibly by interest rates, are a more reliable indicator of the monetary authorities' impact on the economy. According to this view, monetary restraint is indicated by high or rising interest rates, and expansive policy is denoted by low or declining interest rates. However, the record offers little evidence of the reliability of interest rates as an indicator of monetary influences. ${ }^{4}$ Interest rates are determined, as are other prices, by demand and supply. The Federal Reserve can influence the price charged and paid for loan funds in the short rum by influencing the supply of credit, but it can do little, if anything, to influence the demand for credit within a short period. On the other hand, in the longer run the monetary authority affects interest rates importantly by its influence on the demand for credit.

Although the high interest rates of 1968 indicated tight money market conditions, they did not indicate restrictive monetary actions. Growth of Federal Reserve credit and the monetary base accelerated during 1968, and inflationary pressures intensified. An interpretation consistent with both Federal Reserve actions and economic developments concludes that the high interest rates were the result of increased demand for loan funds which, in turn, was stimulated by an earlier rapid monetary expansion.

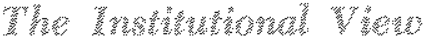

A third view, which emphasizes imperfections in the economy, feels inflation is caused by the sellers of goods and services, including labor, who are continually trying to get a larger share of overall revenue. But continued cost-push inflation, while maintaining high employment, is possible only if the Government validates the attempts by sellers to get higher prices by pursuing an inflationary policy.

Cost-push inflation is usually a delayed response to an earlier excessive demand. Cost-push forces are usually most intense in periods following a rapid rise in total spending and the accompanying "demandpull" price increases. At these times there are usually inllationary anticipations and inequities caused by lags in adjustments of some wages and other prices. Those emphasizing costupush as the chief cause of inflation are more willing than others to accept the inefficiencies of wage and price controls to moderate inflationary excesses. Such controls are difficult to administer, cause inequities, misallocate resources, impinge on freedom, and reduce the flexibility needed to reach equilibrium.

${ }^{4}$ See "Interest Rates, 1945-1965", this Review, October 1965. 


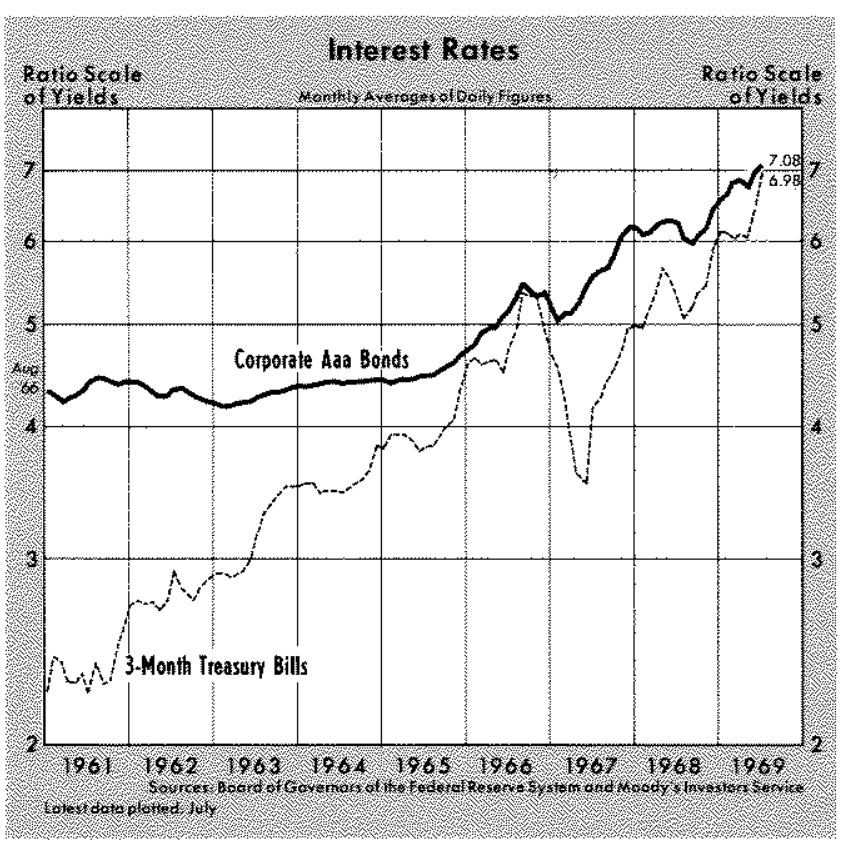

Recent Actions to Halt Inflation

In recent months, both fiscal and monetary actions have become more restrictive. Efforts to obtain the renewal of the surtax and cancellation of tax investment credit represent attempts to maintain the fiscal stance. But if primary reliance were to be placed upon fiscal measures to restrain total spending, it might be held that the steps which have been taken in the past year have probably not been of an adequate magnitude. The annual rate of surplus of the highwemployment budget in the first half of 1969, of $\$ 8$ billion, compares with an average of $\$ 12$ billion in the 1960-63 period when the economy recovered from recession. In order for the current budgetary surplus to stand in the same relation to total spending that it did in 1961-63, it would need to be at a $\$ 20$ billion annual rate rather than the current $\$ 8$ billion rate. And, if the budget influence were thought of in terms of movement rather than the level of highemployment surplus or deficit, it may be observed that little change is currently plamned from second quarter of 1969 through the first half of 1970 . By conventional interpretation of the influence of the budget on growth of total spending, the current situation may be interpreted as about "neutral" rather than either expansive or contractive.

Monetary policy has been much less stimulative since last December relative to the preceding two years, no matter what indicator is examined. Both short" and long-term market interest rates have risen sharply. Yields on three month Treasury bills have risen from 5.94 per cent last December to 6.98 per cent in July, and rates on highest-grade corporate bonds have gone up from 6.45 per cent to 7.08 per cent.

Growth of monetary aggregates has also slowed. Money stock has increased at a 2.2 per cent annual rate since December 1968 , after rising at a 6.5 per cent rate in the two previous years; the demand deposit component has risen at a 1.0 per cent rate, compared with a 6.4 per cent rate in the earlier period; bank credit has grown at a 3.6 per cent rate, down from an 11.4 per cent rate, and money plus time deposits has decreased at a 2.6 per cent rate, against an earlier 10 per cent rate of increase.

It might be noted, however, that the degree of monetary restraint in the past seven months, as a whole, may have been less than it has been in some other comparable periods in recent history. The recent seyen month increase of money at a 2.2 per cent rate, down from an earlier 6.5 per cent rate, compares with a nine month period of no change in 1966 following a 6 per cent rise in the previous year. In 1962, money was about unchanged for seven months, and in 1959-60, when it might be concluded that restraint became too great, money declined 2.3 per cent in a twelve month period.

In the past three months, however, strategic monetary magnitudes have declined or their rate of growth has sharply decelerated. Total member bank reserves have fallen from about $\$ 27.8$ billion in May and early June to $\$ 26.8$ billion in the last four weeks. These reserves had shown little net change

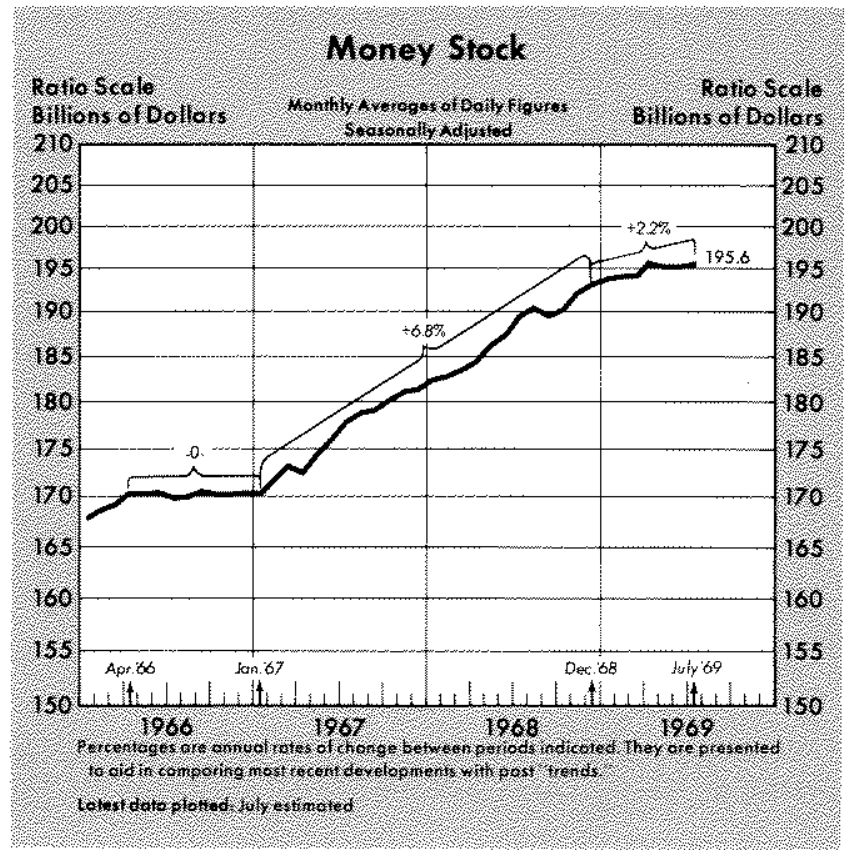


from early January to May. The money stock has shown little net change on balance since the beginning of April. From December to April, money had increased at a 4 per cent annual rate. The demand deposit component of money has declined at about a 3 per cent annual rate in the last three months, after increasing at about a 4 per cent rate from December to April. Money market conditions as measured by changes in interest rates tightened markedly in May and June. Since late June, interest rates appear to have leveled off in spite of continued monetary restriction.

\section{Effect on the Real Sector}

The slower monetary expansion since last December may have already had some effect on total spend. ing, but experience indicates that the major effects are likely yet to come. Retail sales, housing starts, and employment appear to have slowed, although frequently short-term movements in these series are misleading. Retail sales have recently shown little net change, compared with a 7 per cent increase in 1968; housing starts have declined for five consecutive months, and total employment has been on a plateau since February. On the other hand, industrial production has continued to increase at about the 5.7 per cent annual rate of the past two years, personal income has continued its stronge advance, and unemployment has remained at an unusually low level.

Preliminary second quarter GNP figures indicate continued excessive total spending and inflation. Total

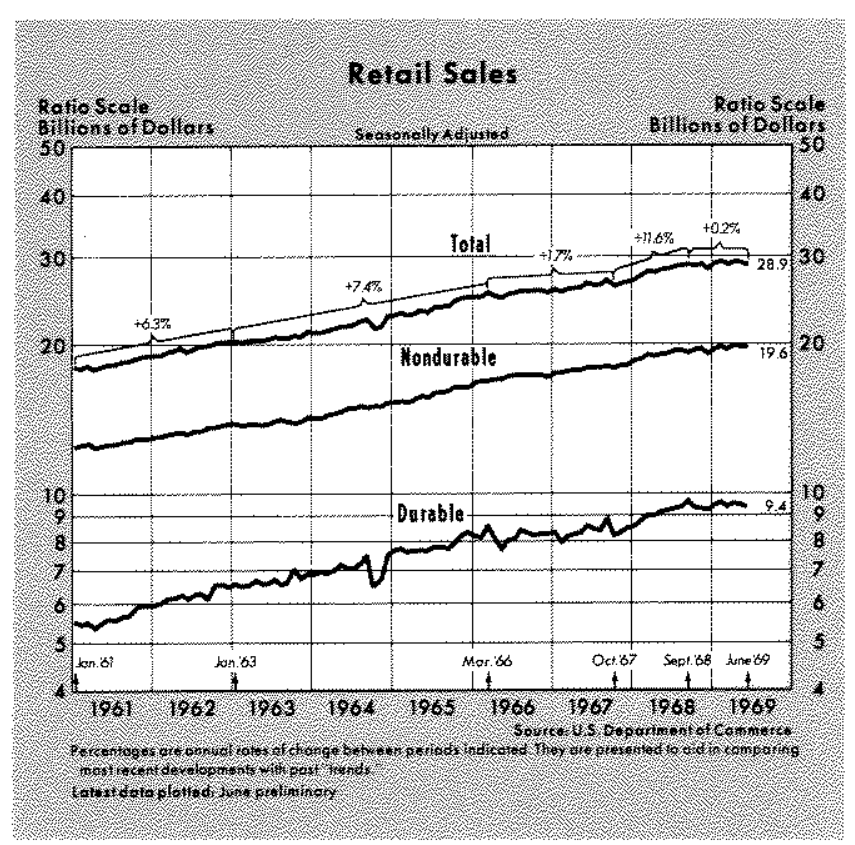

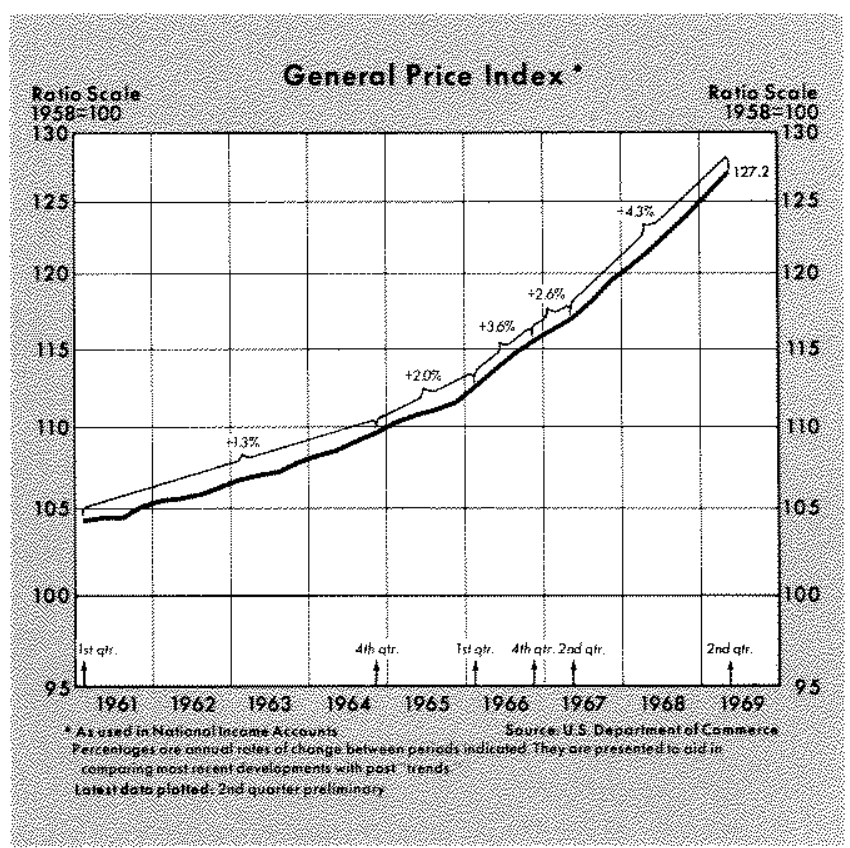

spending grew at a 7.4 per cent annual rate from the first to second quarter, slower than the 8.7 per cent rate of the past two years but still more rapidly than the estimated 4 per cent rate of growth of productive potential. Price increases have not slowed, with the general price index rising at a 4.9 per cent rate in the second quarter, compared with the 4.3 per cent rate of the past two years.

Real GNP has grown at a slower annual rate each quarter since the second quarter of 1968 , rising at a 2.3 per cent rate in the second quarter of this year, 2.6 per cent rate in the first quarter, 3.2 per cent rate in the fourth quarter last year, 4.0 per cent rate in the third quarter and 7.4 per cent in the second. This slowing occurred as the economy approached capacity and could not maintain the earlier rapid pace. Further, if the inflation is to be moderated and the interest rate trend reversed, growth of real production must probably decelerate before resuming a growth rate comparable to the growth of productive potential.

\section{When Will Price Rises Slow?}

In the past, real economic growth has generally slowed prior to a reduction in the rate of price ad. vances. Ustally after demand growth has slackened, there are continued price and wage advances as part of a delayed reaction to the previous economic environment. In accordance with the usual time sequence, we are not likely to see a significant deceleration of price increases until the growth of total spending has been moderated for a considerable period. 